\title{
A survey on the process of knowledge representation of the small banana farmers (Musa spp.) in mangaratiba, rj
}

\author{
Um levantamento sobre o processo de representação do conhecimento dos \\ pequenos produtores de banana (Musa spp.) em Mangaratiba, rj
}

\section{Emanuele Nunes de Lima Figueiredo Jorge ${ }^{1}$ (D) , Cláudio Miceli de Farias' ${ }^{\text {(D) }}$ Sérgio Thode Filho" iD}

\author{
'Federal University of Rio de Janeiro, Rio de Janeiro, RJ, Brazil \\ III Federal Institute of Rio Janeiro, Rio de Janeiro, RJ, Brazil
}

\begin{abstract}
The banana, the world's most widely produced and commercialized fruit, is grown in all tropical regions of the world, being strongly present in local businesses and subsistence crops serving as an important source of nutrients for the poorest populations. In the state of Rio de Janeiro it is commonly found in hillside and difficult access areas, where most other crops would not be able to settle and, because of this, is grown with inadequate management or insufficient, resulting in low productivity in the areas of Rio de Janeiro. The objective of the present work is to carry out a survey of smallholder information from the Vale do Rio Sahy Association in Mangaratiba, RJ, to enable the representation of knowledge in this domain. From the data collected in this research, it was realized that producers have been engaged in this activity for a long time. However, it was found that the knowledge used to production is extremely tacit, without systematization. The variety of banana species (Musa spp.) grown in the production area of the association's small farmers. The knowledge transfer process knowledge to the knowledge base of an expert system is called knowledge acquisition, where it involves extract all the knowledge from the source of the specialists to systematically represent in a coded form the domain information in an appropriate medium. It was observed, even if preliminarily, that this knowledge are not represented in a database for consultation. Thus, there is a need to define human expertise or producers capable of representing in a technological way data that can be conveniently accessed for Problem solving. In view of the evidence presented in the research, the use of representation of human knowledge (small local producers) to feed and train the system according to the domain presented. Thus, enabling the prototype to help understand climate and soil variables and collaborate in decision making.
\end{abstract}

Keywords: Technology; Arduino; Intelligent systems; Agricultural production 


\section{RESUMO}

A banana (Musa spp.), fruta mais produzida e comercializada no mundo, é cultivada em todas as regiões tropicais do mundo, estando fortemente presente no comércio local e nas culturas de subsistência, servindo como importante fonte de nutrientes para as populações mais pobres. No estado do Rio de Janeiro é comumente encontrado em áreas de encostas e de difícil acesso, onde a maioria das outras lavouras não conseguiria se estabelecer e, por isso, é cultivado com manejo inadequado ou insuficiente, resultando em baixa produtividade nas áreas de. Rio de Janeiro. O objetivo do presente trabalho é realizar um levantamento de informações dos produtores rurais da Associação Vale do Rio Sahy em Mangaratiba, RJ, para possibilitar a representação do conhecimento neste domínio. A partir dos dados coletados nesta pesquisa, percebeu-se que os produtores estão engajados nesta atividade há muito tempo. Porém, constatou-se que o conhecimento utilizado para a produção é extremamente tácito, sem sistematização. A variedade de espécies de bananeiras (Musa spp.) Cultivadas na área de produção dos pequenos agricultores da associação. O processo de transferência de conhecimento para a base de conhecimento de um sistema especialista é denominado aquisição de conhecimento, onde envolve extrair todo o conhecimento da fonte dos especialistas para representar sistematicamente de forma codificada as informações do domínio em um meio apropriado. Observou-se, ainda que preliminarmente, que esses conhecimentos não estão representados em um banco de dados para consulta. Assim, existe a necessidade de definir expertise humana ou produtores capazes de representar de forma tecnológica dados que possam ser convenientemente acessados para resolução de problemas. Tendo em vista as evidências apresentadas na pesquisa, o uso da representação do conhecimento humano (pequenos produtores locais) para alimentar e treinar o sistema de acordo com o domínio apresentado. Desta forma, possibilita que o protótipo ajude a entender as variáveis do clima e do solo e colabore na tomada de decisões.

Palavras-chave: Tecnologia; Arduino; Sistemas inteligentes; Produção agrícola

\section{INTRODUCTION}

Among the countless varieties of fruit produced in Brazil, the banana stands out, not only because it is the most disseminated, but also because it is the most consumed by all social classes (DE ARAÚJO FILHO, 2017). Banana, is the fruit of greatest production and commercialization worldwide, is grown in all tropical regions of the world, being strongly present in local market and crops subsistence serving as an important source of nutrients for the poorest populations. In the state of Rio de Janeiro it is commonly found in hillside and difficult áreas access, where most other cultures would not be able to establish and, because of this, it is cultivated with inadequate or insufficient, resulting in low productivity in Rio de Janeiro areas (NUNES, 2018).

In Rio de Janeiro, the Costa Verde region is made up of the municipalities of Itaguaí, Mangaratiba, Angra dos Reis and Paraty, and has favorable edaphoclimatic conditions for the development of banana crops. Therefore, the region stands out in the production of 
bananas in the state, in particular the municipality of Mangaratiba. The Municipality of Mangaratiba is located $105 \mathrm{~km}$ from the city of Rio de Janeiro, it has an area of 358,982 km2 and an estimated population of 42,415 habitants. According to data from IBGE (2018), Mangaratiba is the municipality in the state of Rio de Janeiro with higher production banana $(32,760$ ton.) and also has the largest área harvested $(4,670 \mathrm{ha})$ in relation to other municipalities in the state. However, the average yield is $7,015 \mathrm{~kg} / \mathrm{ha}$, very low income, with the Municipality occupying currently 56th in the state of Rio de Janeiro (SILVA, 2018).

Currently, banana production in Mangaratiba is almost extractivet and the harvesting, conditioning and processing are done improperly. All of these factors result a reduction in the quality of the final product, making the average income is very low, and consequently, the product loses much value, in this way, the banana produced is of low quality and without any commercial standard (SILVA, 2018).

In this context, the Internet of Things (IOT) can help. The loT is a global network that links physical objects using cloud computing, web applications and communications network. It allows devices to communicate, access information on the Internet, store and retrieve data and interact with users, creating environments intelligent, widespread and always connected (DOUKAS, 2012). Besides that, to model information and knowledge of small local farmers represented by them empirical, we will use the concept of knowledge representation that will allow to formalize in a symbolic this domain and will enable the processing and system inferences according to the rule base established (EITER, 2019).

The objective of the present work is to a survey of the knowledge representation with banana farmers of the Vale do Rio Sahy Association in Mangaratiba, RJ, to enable the knowledge representation of that domain.

\section{MATERIAL AND METHODS}

To carry out this work, a survey was carried out among November 02 and 06, 2020, from $2 \mathrm{pm}$ to $5 \mathrm{pm}$ at the Vale do Rio Sahy Association in Mangaratiba on RJ. The instrument used was the questionnaire structured, containing 10 closed questions. For selection From the sample, 15 banana farmers were randomly chosen among the 28 associates. 
From the point of view the classification of the research, it was based on the taxonomy presented by (VERGARA, 2010), which qualifies it in relation to two aspects: as to the ends and as to the means. How much at the end, the research can be considered exploratory. Exploratory, as there is a lack of studies on the aspects related to knowledge representation applied to agribusiness, especially banana production (Musa spp.), to solve complex problems, data processing, analysis, modeling and monitoring. As for the means, research can be classified as field, because it occurred through direct observation and interviews with small producers primary data collection.

The estimated confidence interval was $95 \%$ and the maximum estimated margin of error is $5 \%$, more or less, on the results found. The software used for tabulation and data processing was SigmaPlot 12.5 .

\section{RESULTS AND DISCUSSION}

According to figure 1 , the survey showed that $73 \%$ of producers have been operating for over 10 years producing bananas (Musa spp.) And other crops. Average monthly production varies from 1 to 3 tons. When asked about important climatic variables for its production, the sun, the rain and temperature appear evenly distributed importance (33\%). Air humidity and wind are the minor variables. Regarding how monitored these variables, all (100\%) said that they used only field observation.

Continue... 
Figure 1. Exploratory survey about the knowledge representation of the banana farmers in the municipality of Mangaratiba, RJ

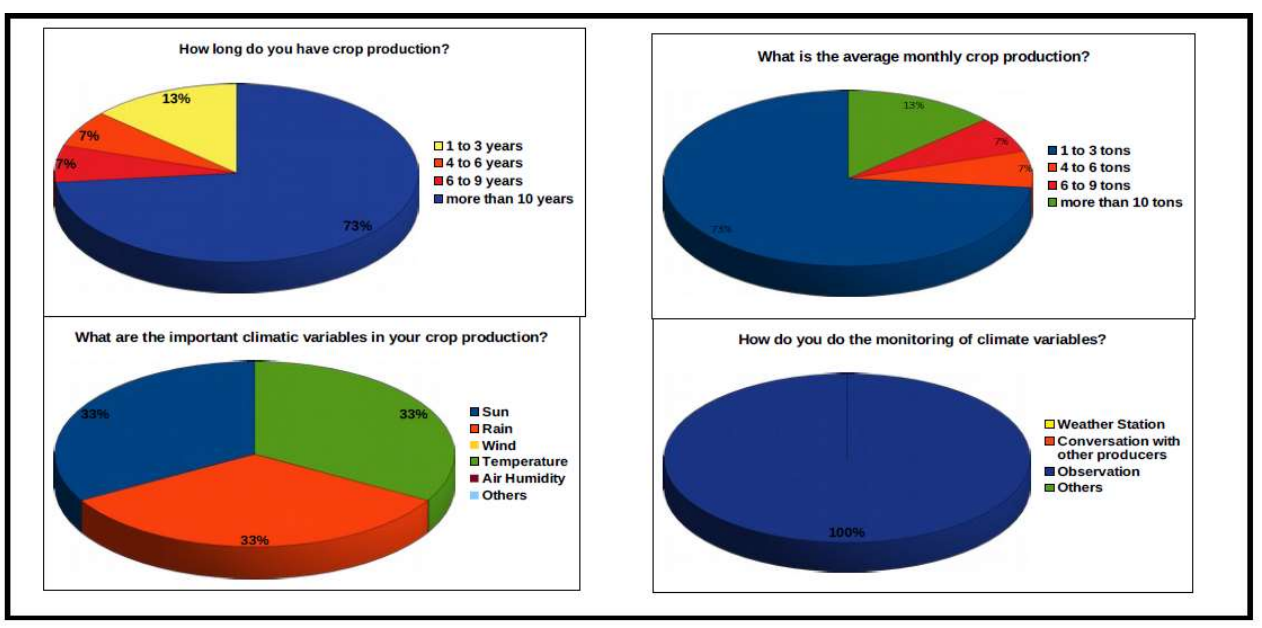

Source: Authors (2021)

According to Figure 2, 93\% of banana farmers said that it is important to monitor some characteristic from soil. According to them, the most important variables for the soil monitoring are, respectively: $\mathrm{pH}$ and humidity (42\%), followed by nutrients (12\%) and others (4\%). In addition, how they knew the right moment in terms for the cultivation of bananas (Musa spp.), $73 \%$ stated that it is through field observation. However, $13 \%$ said they know the right time to harvest, from the size of the fruit. However, $7 \%$ said that use average planting time and other assessments, such as: color, thickness of the fruit, etc.

Figure 2. Exploratory survey about the knowledge representation of the banana farmers in the municipality of Mangaratiba, RJ

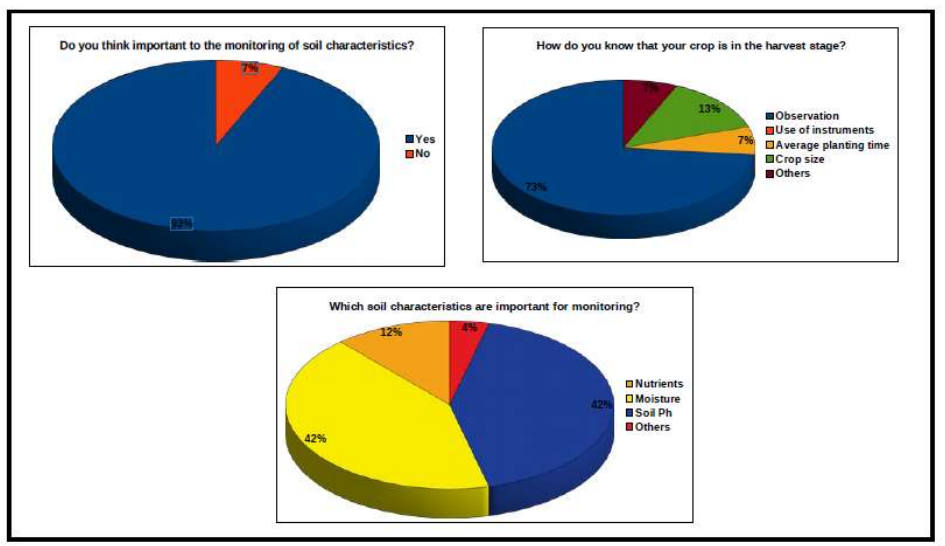

Source: Authors (2021) 
The interviewees said that they know the right time for planting, according to knowledge previous pass by someone in the family (73\%). Of the $26 \%$ remainder, $13 \%$ reported that more experienced producers they passed on this information and the other $13 \%$ know the time right for planting by trial and error. When asked on monthly losses in production, $73 \%$ reported that it is in average of $20 \mathrm{~kg}$. Finally, about a technological system that would allow the monitoring of some environmental variables that would reduce losses, increase the quality of cultivation and that could be used by him at any time of the day, $100 \%$ of respondents answered yes (Figure 3).

Figure 3. Exploratory survey about the knowledge representation of the banana farmers in the municipality of Mangaratiba, RJ

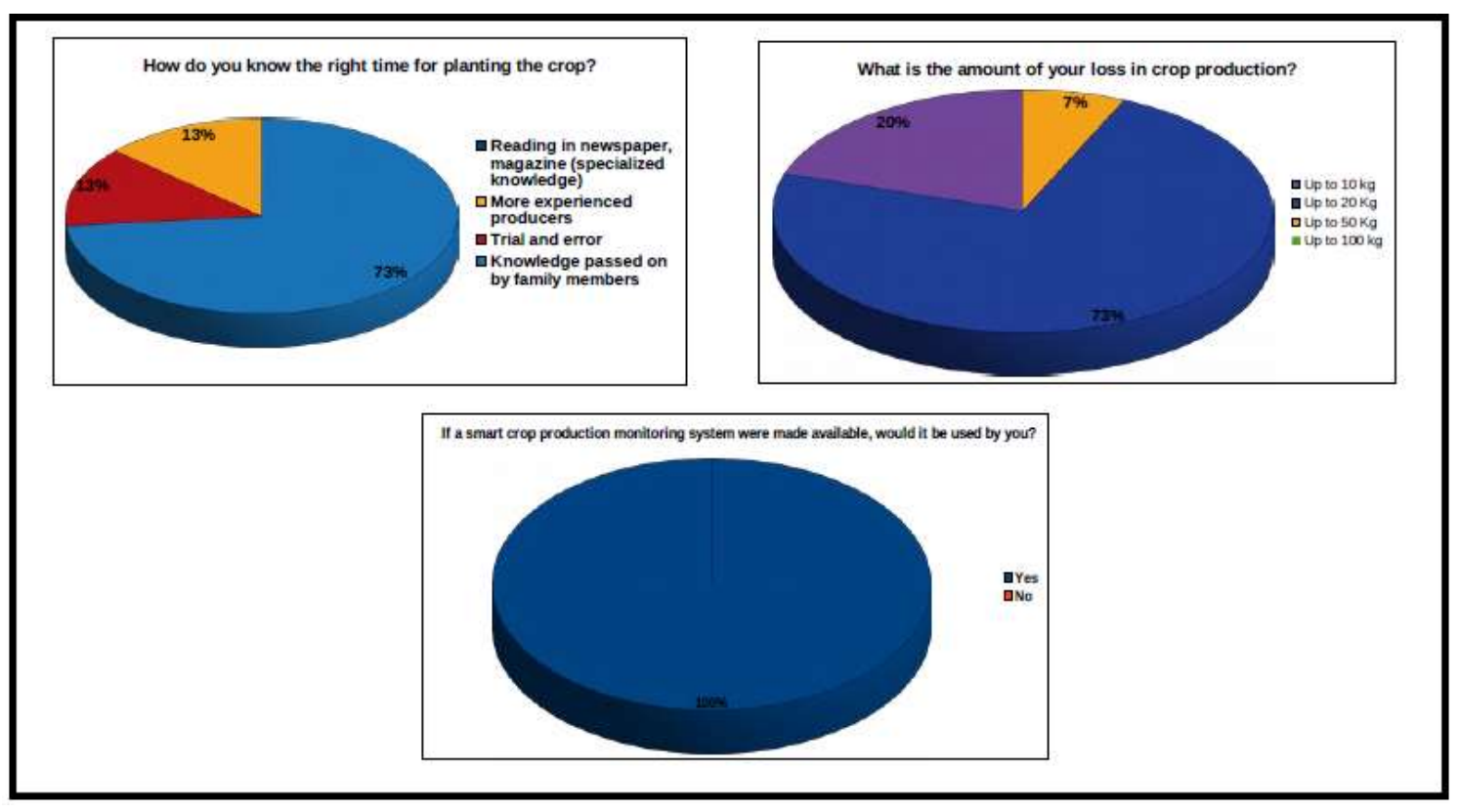

Source: Authors (2021)

From the data collected in this survey, it was reported that producers to work in this activity for quite time. However, it was found that knowledge used for production is extremely empirical, without systematization. The variety of species of bananas (Musa spp.) that are grown in the production área association's small farmers. Furthermore, in the other crops are planted, such as: vegetables, various fruits and vegetables. The process of transfer of human knowledge to the database knowledge of an expert system is called knowledge acquisition, which involves extracting all the knowledge of the source of the experts to 
represent systematically in a coded form the information about the domain in an appropriate medium (EITER, 2019).

Thus, it is showed that most producers interviewees have a lot of empirical knowledge, empirical method for planting bananas (Musa spp.). Including using the Agroforestry concept, in which species perennial forests are planted together with agricultural crops and animal breeding. This protects the bananal crops of the physical weathering. However, it was observed, even if preliminarily, that this knowledge is not represented in a database for consultation. Thus, there is a need to define human expertise or of producers capable of representing technologically a given that it can be conveniently accessed for problem solving. When developing a system, a good solution depends on good representation. For this, the approach rule based has proven to be very efficient in domains simple. The main advantages of a system based on rules include the ease of formulating and emulating the process human cognitive, decision making ability, and also the ease of knowledge representing in a homogeneous structure and modular shape (DHEIR, 2019).

Proposals from expert systems that are presented to help farmers is of great interest to the agricultural sector, as they can obtain faster and more accurate for the problems traditionally presented. Generally, a specialist system based on knowledge representation is made up of four main components, which are: knowledge base, working memory, an inference engine and an interface of user.

According to (KHALIL, 2019), the proposed expert system performs the diagnosis of apple diseases showing the symptoms. The system asks the user to choose the correct symptoms of apple (Malus domestica) disease on each screen displayed. At the end of the dialogue session, the system specialist provides the user with a suggestive diagnosis and the disease recommendation. According to (DHEIR, 2019), a specialist system similar to (KHALIL, 2019) that proposes the use knowledge base containing images of guava (Psidium guajava) diseases and how they evolve and attack the stem, the branches, the leaves and especially the fruit.

Through a inference engine, which is a mechanism that allows derive new knowledge, using the database knowledge specified by the domain it is possible to compare the state 
of the fruits and immediately make decisions to better fight pests without the help or assistance of a specialist professional.

According to (ALTAF, 2020), monitoring focused on banana ripening (Musa Spp.), Demonstration of the use of a wireless sensor network (RSSF) based on Xbee. The role of the network architecture of the proposed work, discusses in detail about the ability to monitor the condition of all parameters of altitude diagnosis and ripening stages of the banana (Musa Spp.). In addition, different features are part of the prototype such as, the use of a gas sensor. These resources are used for training in These resources are used for training in the Artificial Neural Network (ANN) through the Back Propagation (BP) algorithm Backpropagation of error. The experimental results demonstrate that the designed RSSF architecture can identify the condition of the banana (Musa spp.) in the storage area (postharvest). $\mathrm{n}$ view of this challenge, a system of monitoring for low cost agricultural environments, similar to that presented by (VERGARA, 2010) using loT and knowledge representation to assist the process of decision making in the planting and harvesting process, monitoring climate and soil variables for the best harnessing crop.

\section{CONCLUSIONS}

This work showed that there are methodologies for mitigate the existing impacts on the production of some fruits. The systems presented are adherent to the producers and can get faster and more accurate for the problems traditionally presented, collaborating with local agriculture. In view of the evidence presented in the survey, it is considered fundamental the use of knowledge representation (banana farmers) to feed and train the system according to the domain presented. Thus, enable the prototype to help understand the climatic and soil variables and collaborate in making decision.

\section{ACKNOWLEDGEMENTS}

We thank the Association of Small Farmers of the Vale do Rio Sahy de Mangaratiba in RJ,for all the help and collaboration for this research to be developed. To the Prof $\mathrm{Dr}$ 
Fernando Gomes Souza Jr for the opportunity to participate in ConBraPA 2020, where this work started. To the whole organizing committee of ConBraPA 2020 for learning from each of you. The PROPPI - Dean of Research, Graduate Studies and Innovation at IFRJ and finally to the Graduate Program in Informatics at UFRJ.

\section{REFERENCES}

ALTAF, S., Ahmad, S., Zaindin, M., \& Soomro, M. W. (2020). Xbee-based WSN architecture for monitoring of banana ripening process using knowledge-level artificial intelligent technique. Sensors, 20(14), 4033.

DE ARAÚJO FILHO, J. R. (2017). A cultura da banana no Brasil. Boletim Paulista de Geografia, (27), 27-54.

DOUKAS, C. (2012). Building Internet of Things with the ARDUINO. CreateSpace Independent Publishing Platform.

DHEIR, I., \& ABU-NASER, S. S. (2019). Knowledge Based System for Diagnosing Guava Problems. International Journal of Academic Information Systems Research (IJAISR), 3(3), 9-15.

EITER, T., \& KERN-ISBERNER, G. (2019). A brief survey on forgetting from a knowledge representation and reasoning perspective. KI-Künstliche Intelligenz, 33(1), 9-33.

KHALIL, A. J., BARHOOM, A. M., MUSLEH, M. M., \& ABU-NASER, S. S. (2019). Apple Trees Knowledge Based System.

NUNES, F. (2018). Avaliação fitossanitária em bananeiras sob sistema agroecológico. Embrapa Agrobiologia-Tese/dissertação (ALICE).

SILVA, A. D. O. (2018). Restructuring of the agribusiness sweets, through banana processing and strengthening of family farming in the municipality of Mangaratiba, rj. , [s.I.]Tese/dissertação.

VERGARA, S. C. 2010. Research projects and reports in administration. São Paulo: Atlas.

\section{AUTHORSHIP CONTRIBUTIONS}

\section{1-Emanuele Nunes de Lima Figueiredo Jorge}

$\mathrm{PhD}$ student in the Postgraduate Program in Computer Science https://orcid.org/0000-0002-6766-6072 | E-mail: emanuele.jorge@ifrj.edu.br Contribution: Conceptualization, Data curation, Formal Analysis, Investigation, Methodology, Software, Validation, Visualization, Writing - original, draft, review \& editing 


\section{2-Sergio Thode Filho}

PhD in Sciences

https://orcid.org/0000-0001-6669-2677 | E-mail: sergio.thode@ifrj.edu.br

Contribution: Conceptualization, Formal Analysis, Methodology, Project administration, Software, Supervision, Validation, Visualization, Writing - review \& editing

\section{3-Claudio Miceli de Farias}

PhD in Informatics

https://orcid.org/0000-0002-1927-7398 | E-mail: claudiofarias@nce.ufrj.br

Contribution: Project administration, Supervision, Validation, Writing - review \& editing

\section{HOW TO QUOTE THIS ARTICLE}

Jorge, E. N. L; Filho, S. T; Farias, C. M. A survey on the process of knowledge representation of the small banana farmers (Musa spp.) in mangaratiba, rj. Revista de Gestão, educação e tecnologia ambiental, V.25, e7, 2021. Available from: https://doi.org/10.5902/2236117064017. Accessed: Month Abbreviated. Day, year. 